\title{
Diatom-inferred salinity records from the Arctic Siberian Margin: Implications for fluvial runoff patterns during the Holocene
}

\author{
Henning A. Bauch ${ }^{1}$ \\ GEOMAR Research Center for Marine Geosciences, Kiel, Germany \\ Yelena I. Polyakova \\ Department of Geography, Moscow State University, Moscow, Russia
}

Received 12 September 2002; revised 12 September 2002; accepted 28 January 2003; published 19 April 2003.

[1] Diatom assemblages were employed to study temporal changes of Siberian river runoff on the Laptev Sea shelf. Using a correlation between freshwater diatoms (\%) in core-top sediments and summer surface water salinities from the inner Kara Sea, salinity conditions were reconstructed for a site northeast of the Lena River Delta (present water depth $32 \mathrm{~m}$ ) since 9 calendar years (cal) ka. The reconstruction indicate a strong, nearcoastal, and river-influenced environment at the site until about $8.6 \mathrm{cal}$ ka. Corroborated by comparison with other proxy records from further to the east, surface salinities increased from 9 to 14 until about 7.4 cal ka, owing to ongoing global sea level rise and synchronous southward shift of the coastline. Although riverine water became less influential at the site since then, salinities still varied between 12.5 and 15, particularly during the last 3.5 kyr. These more recent salinity fluctuations agree well with reconstructions from just north of the Lena Delta, emphasizing the strong linkage between shelf hydrography and riverine discharge patterns in Arctic Siberia. INDEX TERMS: 3022 Marine Geology and Geophysics: Marine sediments - processes and transport; 3030 Marine Geology and Geophysics: Micropaleontology; 3344 Meteorology and Atmospheric Dynamics: Paleoclimatology; 4267 Oceanography: General: Paleoceanography; KEYWORDS: diatoms, land-shelf interaction, Holocene river-runoff, Arctic Siberia

Citation: Bauch, H. A., and Y. I. Polyakova, Diatom-inferred salinity records from the Arctic Siberian Margin: Implications for fluvial runoff patterns during the Holocene, Paleoceanography, 18(2), 1027, doi:10.1029/2002PA000847, 2003.

\section{Introduction}

[2] The present state of the Arctic Ocean, and thus its influence on the global climate system, is largely reflected in patterns of sea ice formation and circumarctic oceanatmosphere circulation [Proshutinsky and Johnson, 1997; Dickson, 1999]. In this high-latitude region, both of these processes are also related to the specific water mass and seaice conditions imparted by salinity variations on the surrounding shelves [Aagaard, 1989]. Because of a strong riverine connection between the land and shelves, the salinity of the upper Arctic Ocean hydrology is directly influenced by the amount of fluvial runoff [Bauch et al., 1995], freshwater which is mainly supplied from the Siberian side (Figure 1).

[3] Since the wide Siberian shelves link the Arctic Ocean with the Siberian hinterland through large rivers, it seems imperative to investigate sediment records from the shallow Siberian shelves, in order to better understand Arctic processes on longer timescales. The modern shelf sediment budget in these regions is balanced to a seasonally varying degree by inputs from rivers, marine bioproductivity and

\footnotetext{
${ }^{1}$ Also at Mainz Academy of Sciences, Humanity, and Literature, Mainz, Germany.

Copyright 2003 by the American Geophysical Union. 0883-8305/03/2002PA000847
}

coastal erosion as well as by sediment export through sea ice [Grebmeier et al., 1995; Gordeev et al., 1996; Eicken et al., 1997]. Due to these various processes, the shelf sediments are composed of a mixture of terrestrial and marine organic matter [Fahl and Stein, 1999; Mueller-Lupp et al., 2000], information that can be utilized to reconstruct past changes in Arctic land-shelf interaction [Bauch et al., 1999].

[4] As central part of the vast Eurasian Arctic shelf, the Laptev Sea is regarded a key area to study the influence of Siberian rivers on Arctic Ocean environments [Kassens et al., 1998]. The many rivers draining onto this shelf comprise about $1 / 4$ of the total annual riverine input into the Arctic Ocean [Aagaard and Carmack, 1989]. So far, there was little data available on past hydrology from the Laptev Sea due to a scarcity of sediment cores and the lack of reliable age control of these cores [Holmes and Creager, 1974; Aksenov et al., 1987]. Recent micropaleontological studies now indicate that groups such as diatoms and aquatic palynomorphs offer the opportunity to also investigate past hydrological processes [Bauch et al., 2000; Bauch and Polyakova, 2000; Kunz-Pirrung et al., 2001].

[5] In addition to previously published data of diatom assemblage records in surface samples from the Laptev Sea [Cremer, 1998, 1999; Bauch and Polyakova, 2000], this new study is now based on the relationship between core-top freshwater diatoms and modern surface water salinity in the Kara Sea. The derived correlation is applied to radiocarbonconstrained downcore records recovered from near the Lena 


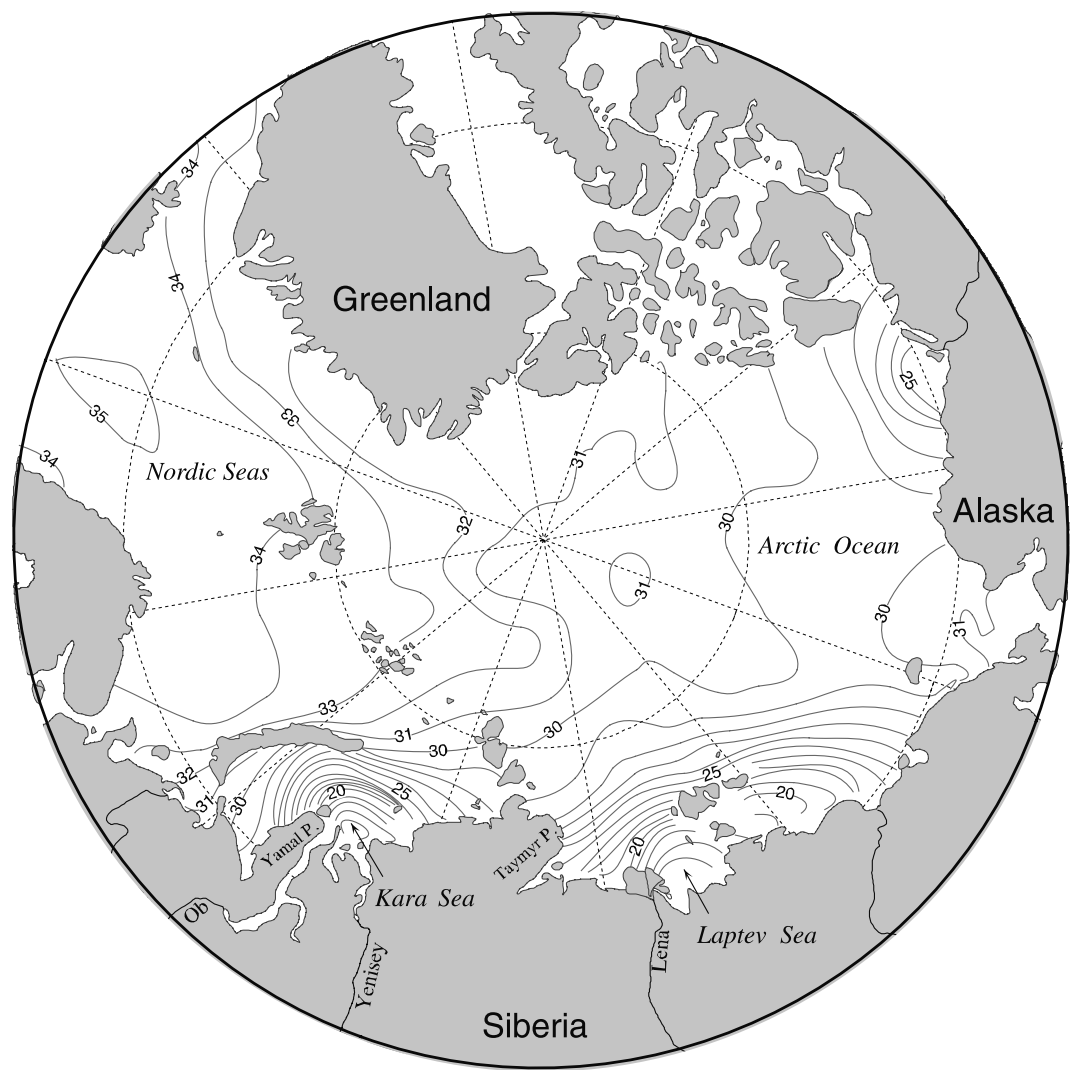

Figure 1. Average summer surface salinity (1950s through 1980s) of the Arctic Ocean and its marginal seas emphasizing the dominance of riverine runoff from the Siberian side $[E W G, 1998]$.

Delta, the largest source of riverine freshwater in the Laptev Sea. By reconstructing the surface salinity quantitatively for the last 9000 calendar years $(9 \mathrm{cal} \mathrm{ka})$, inferences will be made on the effect of the riverine runoff on shelf hydrography as well as on Holocene shelf evolution.

\section{Material and Methods}

[6] Kasten core PS51/92-12 (hereinafter called core 9212) was obtained from the eastern Lena Valley in 1998 (Figure 2). The core is nearly $6 \mathrm{~m}$ long and consists of organic-rich (total organic carbon content varies between $\sim 1.5$ and $2 \%$; T. Mueller-Lupp (personal communication, 2001)), rather homogeneous clayey-silty sediments. To strengthen our interpretation, downcore data of core 92-12 will be compared with previously published records [Bauch and Polyakova, 2000; Bauch et al., 2001a] based on two other cores from similar water depth, core PM9482 in the western Lena Valley and core PM9462 from the Yana Valley (Figure 2). The surface sediments from the Kara Sea were taken onboard R/V Boris Petrov during RussianGerman expeditions to the Kara Sea in 1997 and 1999. The samples cover the inner part of the Kara Sea and the large bays of the $\mathrm{Ob}$ and Yenisey rivers (Figure 3).

[7] To analyze the fossil diatom assemblage, core 92-12 was sampled with open barrel syringes $(10 \mathrm{ml})$ at $5 \mathrm{~cm}$ intervals in the upper $110 \mathrm{~cm}$ and at $10 \mathrm{~cm}$ intervals below this core depth. For modern comparison, the undisturbed

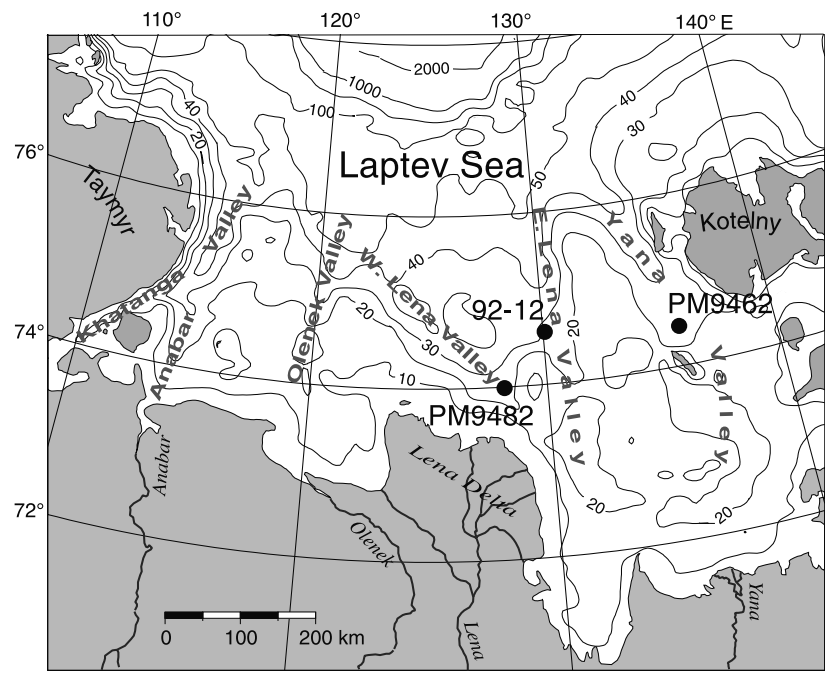

Figure 2. Bathymetric map of the Laptev Sea (depth contours in meters) showing the various river channels incised on the shelf and the position of core $92-12\left(74^{\circ} 36 \mathrm{~N} /\right.$ $130^{\circ} 09 \mathrm{E} ; 32 \mathrm{~m}$ water depth); positions of core PM9462 $\left(74^{\circ} 30 \mathrm{~N} / 136^{\circ} 01 \mathrm{E} ; 27 \mathrm{~m}\right.$ water depth) and core PM9482 $\left(74^{\circ} 00 \mathrm{~N} / 128^{\circ} 11 \mathrm{E} ; 27 \mathrm{~m}\right.$ water depth) are also indicated. 

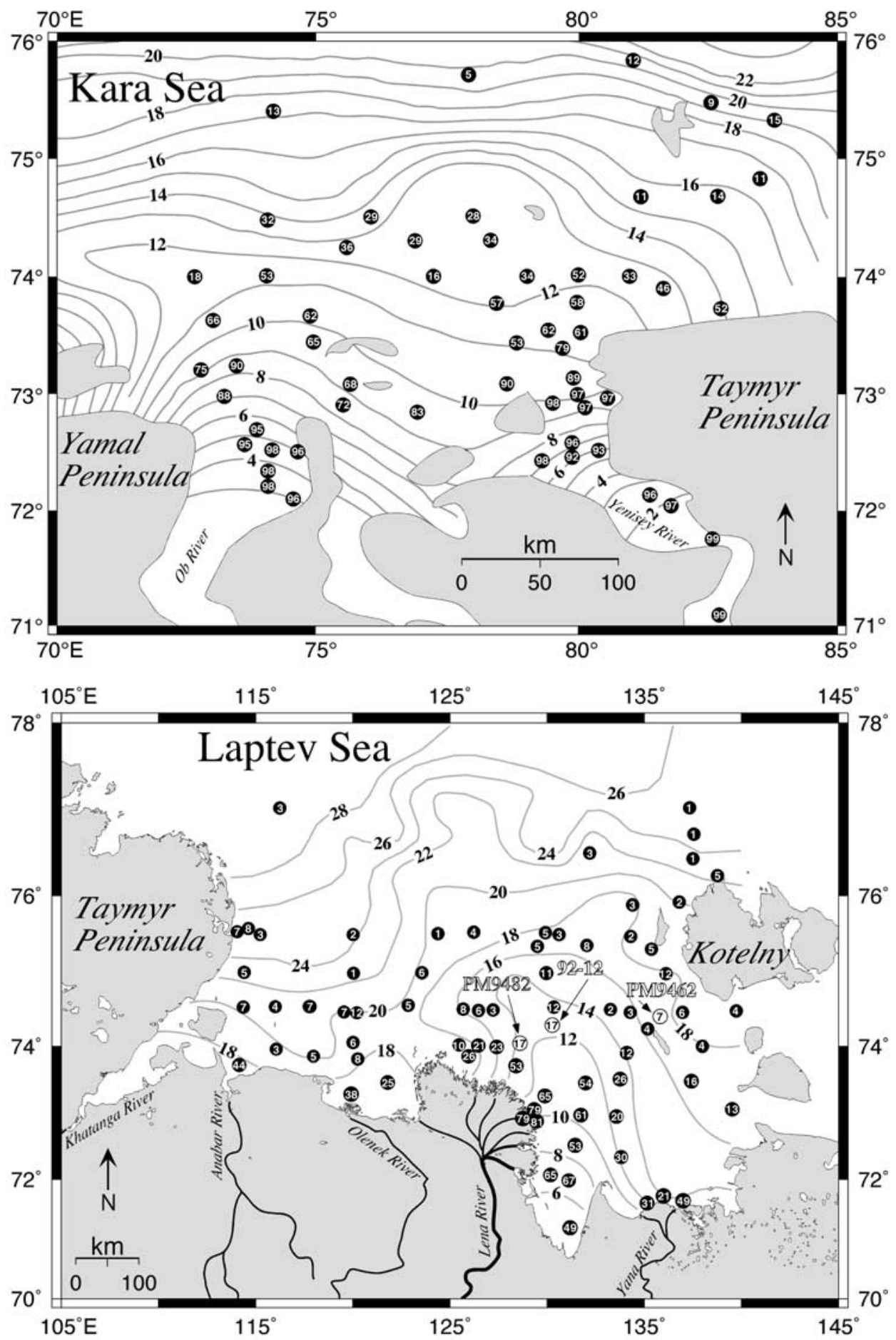

Figure 3. Distribution of freshwater diatoms ( $\%$ of total assemblage) in surface sediments (uppermost 1 $\mathrm{cm}$ from trigger box core) of the Kara Sea and Laptev Sea (note the difference in geographical scale). Isolines show average summer surface salinities on the practical salinity scale (1950s through 1990s); core positions as indicated.

surface sediment from a trigger box core from the same location was also taken. After freeze-drying, the bulk sediments were treated with $\mathrm{H}_{2} \mathrm{O}_{2}(30 \%)$ and $\mathrm{HCl}(10 \%)$. Diatom valves were then concentrated by decantation using distilled water. Slide preparation was carried out following
Battarbee [1973]. The residue were mounted on glass slides with the medium Mountex (Merck, Darmstadt) which has a refraction index of 1.68. The valves were examined under a light microscope at $\times 1000$ magnification. Generally, about 300-400 specimens were counted in each sample. The 
results were then calculated to census data and number of valves per gram of dry sediment (concentrations).

[8] The chronology of core $92-12$ is based on radiocarbon dates measured on bivalves using the accelerator mass spectrometer at the Leibniz Laboratory in Kiel (Germany). All these analyses were carried out on shells with no obvious signs of reworking. Although only single valves were found, the periostracum was still preserved in all cases, implying insignificant post mortem transportation. To account for the reservoir effect of the Laptev Sea, 370 years were subtracted from each of the dated marine shells [Bauch et al., 2001a]. Conversion of radiocarbon dates into calendar years were performed with the program Calib 4.3 [Stuiver et al., 1998].

\section{Modern Setting}

\subsection{Oceanography}

[9] The modern hydrological situation of the Laptev Sea results from the advection of Arctic water masses from the north and annual riverine discharges of about $714 \mathrm{~km}^{3}$ from the south [Ivanov and Piskun, 1995]. The contribution from the Lena River is the highest (about 70\%), water which is mainly directed toward the east and northeast today [Ivanov and Piskun, 1995, 1999]. The influence of the Lena River water on the Laptev Sea hydrology is well-manifested in the surface water salinity (Figure 3) and many other tracers, e.g., dissolved silicon [Pivovarov et al., 1999]. The river ice breaks commonly in early June, but the Laptev Sea becomes relatively ice-free for about 2 months only during the later summer season. Although the general spread of the river waters onto the shelf may vary on an interannual basis [Bauch et al., 2000], but the average longer-term distribution clearly reflects the strong influence of the Lena River water on large parts of the eastern shelf area (Figure 3).

[10] In contrast to the Laptev Sea where the modern Lena River discharges its water through a large delta system, the most significant hydrological feature of the Kara Sea is the huge estuarine bay system that marks the inner part of this Siberian shelf. Although the annual discharge of the two main rivers, $\mathrm{Ob}$ and Yenisey, surpasses the total amount of riverine water runoff into the Laptev Sea [Dmitrenko et al., 1999a], the influence on the Arctic Ocean upper hydrography seems less strong than for the latter due to the semienclosed nature of the Kara Sea (Figure 1). Moreover, most of the shelf surface water that leaves the Kara Sea flows first toward the east before it is being entrained into the Arctic Ocean halocline [Dmitrenko et al., 1999a].

\subsection{Freshwater Diatoms in Surface Sediments}

[11] In order to establish freshwater diatoms as proxy tools for paleosalinity reconstructions, modern diatom data from the inner part of the Kara Sea and from the Laptev Sea shelf are compared (Figure 3). In general, the diatom assemblage on both shelves is virtually the same [Cremer, 1999; Polyakova, 2003] due to comparable environmental conditions which are dominated by the riverine discharge during summer and long ice-covered seasons over the remainder of the year [Dmitrenko et al., 1998]. Minor differences in the species composition between the two regions occur on the outer part of the Kara Sea shelf where there is advection of Atlantic-derived surface waters via the
Barents Sea. On the basis of their ecology, different diatom groups from core-top samples of the Laptev Sea show a relation to various hydrological parameter. While the group of freshwater diatoms mimics the general pattern seen in surface water salinity [Bauch et al., 2000] others, such as the sea-ice diatoms, have been related to the distribution of the drifting pack ice [Bauch and Polyakova, 2000].

[12] The comparison between the freshwater diatoms and surface salinity reveals a very steep gradient close to the Lena Delta. Here, where salinities range below 10 [ $\mathrm{Dmi}$ trenko et al., 1999b], relative abundances in freshwater diatoms are commonly higher than $70 \%$ (Figure 3 ). These high values decrease steeply away from the delta, indicating that rather high proportions of freshwater diatoms are coupled to the marginal zones near the river mouths where salinity is lowest. A similar situation is also recognized for the innermost Kara Sea where our samples cover an approximate average summer salinity range between 4 and 20 (Figure 3). The good correspondence of freshwater diatom distribution in surface sediments with the main pattern of surface water salinity is especially well manifested within the wide outer parts of the $\mathrm{Ob}$ and Yenisei estuaries and the adjacent inner shelf region. Values $>90 \%$ are found in areas of the estuaries where summer salinities are below 6. The overall decrease of freshwater diatom abundance away from the estuary is obviously related to the gradual increase of surface water salinity that goes along with a decreasing influence of riverine freshwater toward the north. The relative abundance of freshwater diatoms steeply decreases in areas with salinity higher than 10-12 and away from the marginal zone of the estuaries. Like in the case with the Laptev Sea, we have observed in the Kara Sea a notable increase in relative proportions of sea-ice diatoms that corresponds to the area of drifting pack ice during winter [Dmitrenko et al., 1998; Polyakova, 2003].

[13] Due to the estuarine nature of the $\mathrm{Ob}$ and Yenisey river mouths, the outflow of water from these two rivers is always directed toward the north with salinities increasing perpendicular to the river flow direction. In contrast, the Lena River water outflow, although flowing mainly eastward today, results in a more complicated salinity pattern on the shelf because of both the deltaic channel system and the annual variations [Dmitrenko et al., 1999b]. Because of this and the fact that our data from the Kara Sea have a better areal coverage of the low salinity range than those from the Laptev Sea, it is reasonable to rely on the Kara Sea data to establish a relationship between relative proportions of freshwater diatoms and average summer salinities (Figure 4).

\section{Sedimentary Setting, Core Chronology, and Diatom Stratigraphy}

[14] The modern shelf topography of the Laptev Sea shelf is marked by characteristic submarine channels that are recognized as submerged river valleys (Figure 2) probably formed during times of lowered sea level [Holmes and Creager, 1974; Kleiber and Niessen, 1999]. On the inner shelf, present-day sedimentation is affected by the fluvial runoff due to amounts of suspended matter carried by the rivers. The suspended material is mainly deposited along 


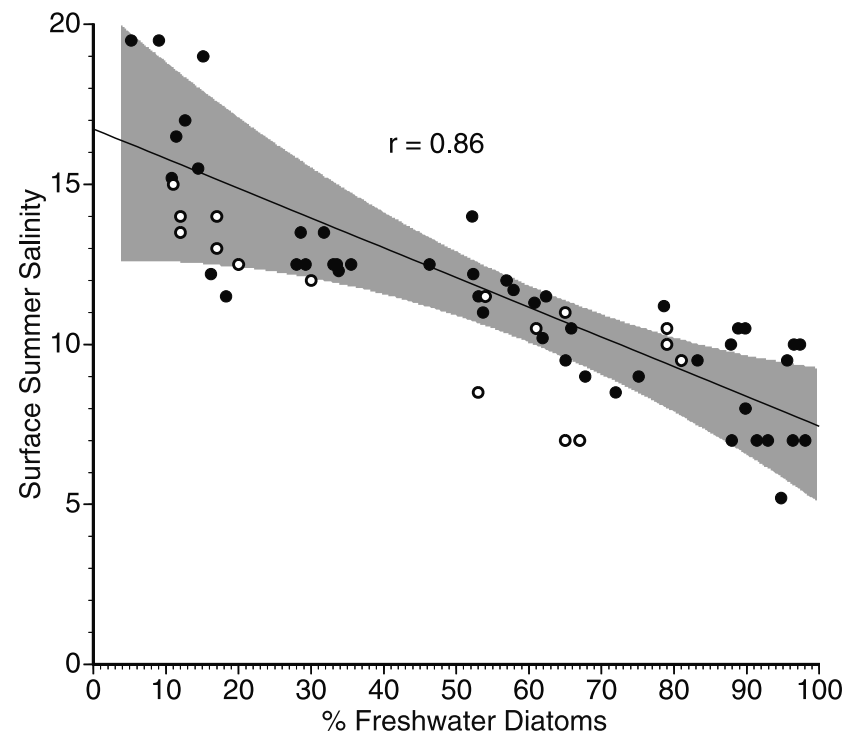

Figure 4. Correlation between freshwater diatoms from core-top sediments in the Kara Sea (filled circles) and average summer surface salinity (1950s through 1990s). Comparison with core-top data from near the Lena Delta in the Laptev Sea (open circles) show that most of these data would fall into the 2-sigma range (shaded gray).

these relict river valleys which, on the middle to outer shelf, also act as major pathways for near-bottom sediment transport [Wegner et al., 2002]. The sediment grain-size texture is rather uniform, mainly composed of clayey silts [Lindemann, 1995; Peregovich et al., 1999]. Occurrence of longer Holocene sediment records are restricted to the inner parts of these submarine channels, which were gradually filled with marine sediments when the shallow shelf became flooded during the last global sea level rise [Bauch et al., 2001b].

[15] According to the radiocarbon dates from core 92-12, the extrapolated calendar age of the base of the core goes back to approximately 9 cal ka (Table 1; Figure 5). A significant reduction in sediment deposition is noted above $300 \mathrm{~cm}$ core depth $(\sim 7.3 \mathrm{cal} \mathrm{ka})$ when average sedimentation rates decrease from $168 \mathrm{~cm} / \mathrm{ky}$ down to $41 \mathrm{~cm} / \mathrm{ky}$. Similar major breaks in sedimentation rates are observed in many sediment cores from various water depths and have been interpreted as resulting from the time-transgressive nature of the Laptev Sea shelf inundation history during early Holocene [Bauch et al., 2001b].

[16] Downcore diatom valve concentrations reveal by far the highest number (up to 27 million valves/g) in the lowermost $70 \mathrm{~cm}$ of the core (Figure 5). A second valve concentration increase is roughly coincident with the interval $300 \mathrm{~cm}$ to $160 \mathrm{~cm}$ core depth, i.e., after the major change in sedimentation rates. Apart from these two sections where significant increases in diatoms occur, downcore valve concentrations in core 92-12 are usually no higher than about 5 million valves $/ \mathrm{g}$. Although the overall trend reflected by the total diatom concentrations is also recognized in the individual group records, direct compar- ison of the species composition of diatom assemblages to these concentration maxima reveal different proportions among the three main ecological groups. While the first concentration peak is mainly formed by freshwater diatoms, dominated by riverine planktonic species, the assemblage of the second peak is largely comprised of marine diatoms, with a dominance of the sea-ice group.

\section{Holocene Diatom Distribution and Species Composition}

[17] The three recognized diatom groups in core $92-12$ consist of a taxonomically diverse assemblage (about 260 species and varieties). The freshwater group is represented by riverine and boggy species of which riverine planktonic species of the genus Aulacoseira (i.e., Aulacoseira italica, A. subarctica, A. granulata) are dominant. Thus their presence in the core can be used to make assumptions on the temporal changes of river water relative to the investigated site. The marine diatom group comprises both, marine and brackish water-marine species of which the latter also includes the sea-ice diatoms.

[18] On the basis of the relative abundances, freshwater diatoms were dominant (up to $85 \%$ ) between approximately 9 and 7.4 cal ka with (Figure 6). Although this time interval is characterized by a general decreasing trend of the freshwater diatoms, there is some noticeable variability in the record. High average percentage values ( $\sim 80 \%$ ) found before 8.6 cal ka go along with diatom concentrations as high as 20.1 million valves $/ g$. After an intermittent decrease in freshwater diatoms down to $50 \%$ centered at $8.2 \mathrm{cal} \mathrm{ka}$, the following average abundance increase of about $60 \%$ is marked by significantly lower valve concentrations (Figure 5). Since $7.4 \mathrm{cal} \mathrm{ka}$, in spite of short time intervals when increases up to $40-50 \%$ are observed (at $5.9,3.5$, and $1.2 \mathrm{cal} \mathrm{ka}$ ), freshwater diatom abundances average about $30 \%$. The youngest sample, which represents the undisturbed top of the trigger box core, yields a value of $17 \%$; this value is comparable to those recognized in other surface samples from nearby site 92-12 (Figure 3).

\section{Hydrological Changes Over the Last 9 cal ka}

[19] Characteristic features of the modern shelf hydrology of the Laptev Sea are the high contribution of riverine runoff discharged onto the shelf during the summer period and intensive formation of pack ice and fast ice during the remaining seasons [Ivanov and Piskun, 1995; Dmitrenko et al., 1998, 1999a, 1999b]. Because the modern Laptev Sea

Table 1. Radiocarbon (AMS) Dates From Core PS51/92-12

\begin{tabular}{llccc}
\hline $\begin{array}{c}\text { Laboratory } \\
\text { Number }\end{array}$ & \multicolumn{1}{c}{$\begin{array}{c}\text { Bivalve, } \\
\text { Species }\end{array}$} & $\begin{array}{c}\text { Depth, } \\
\text { cm }\end{array}$ & $\begin{array}{c}{ }^{14} \text { C age, } \\
\text { Years BP }\end{array}$ & $\begin{array}{c}\text { Calendar Age, } \\
\text { Years BP }\end{array}$ \\
\hline KIA-6877 & Leionucula bellotii & 2 & $590 \pm 25$ & 273 \\
KIA-6878 & Leionucula bellotii & 64 & $1505 \pm 35$ & 1078 \\
KIA-6879 & Macoma cf. moesta & 160 & $1680 \pm 35$ & 1267 \\
KIA-12931 & Macoma calcarea & 210 & $3810 \pm 35$ & 3809 \\
KIA-6880 & Macoma sp. & 300 & $6725 \pm 40$ & 7270 \\
KIA-6881 & Leionucula bellotii & 402 & $7280 \pm 45$ & 7754 \\
KIA-6882 & Macoma sp. & 500 & $7950 \pm 55$ & 8408 \\
\hline
\end{tabular}




\section{PS51/92-12}
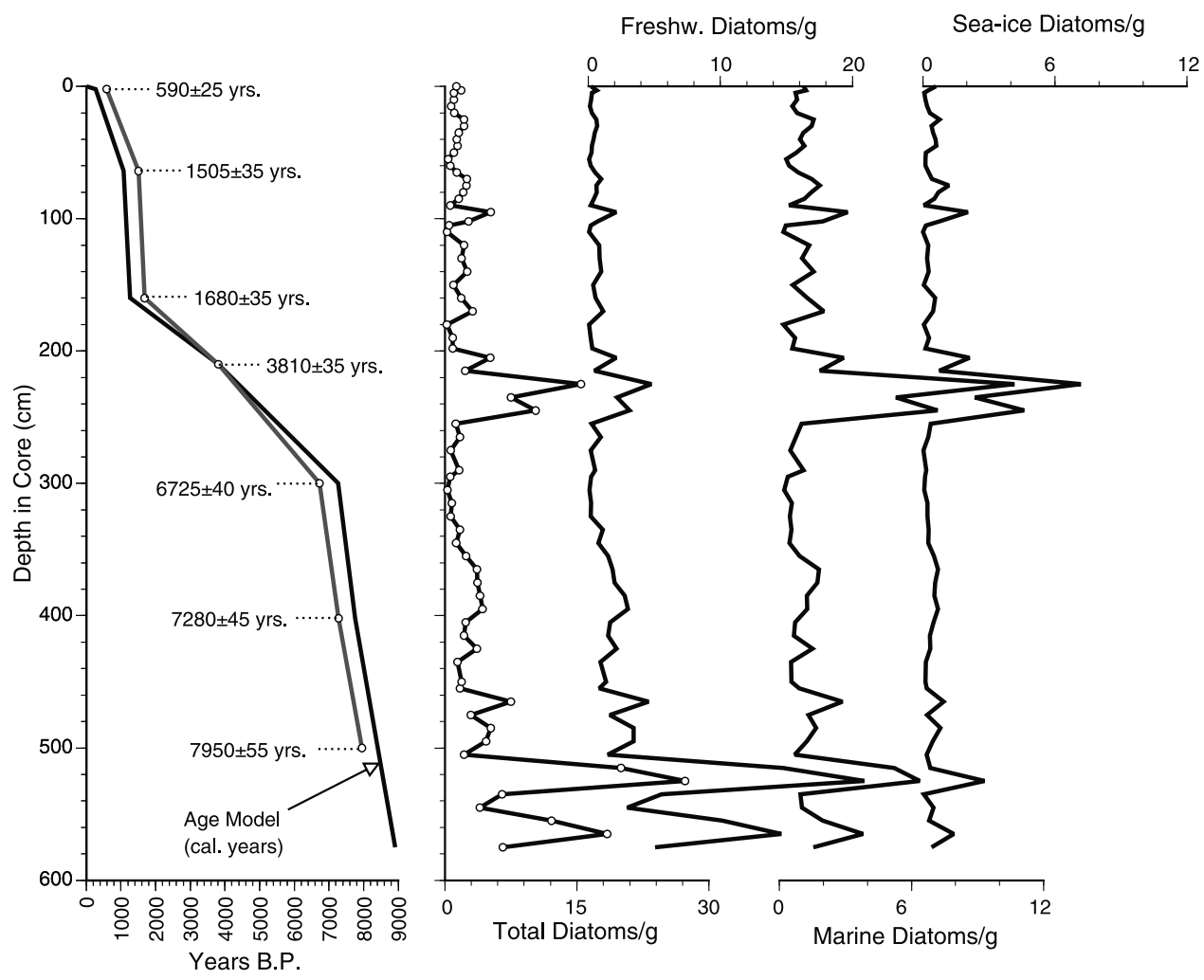

Figure 5. Radiocarbon chronology of core PS51/92-12 and derived age model in comparison with downcore abundance of major diatom groups (in million diatom valves $/ \mathrm{g}$ ).

region started to evolve as shelf sea only during the last postglacial transgression, the increasing sea level was the most influential factor that shaped the early Holocene shelf environment, with particularly high input of terrestrialderived organic matter from coastal erosion and rivers [Bauch et al., 1999; Mueller-Lupp et al., 2000]. Due to the southward retreat of the coastline and river mouths during the transgressive phase, sediment depocenters also shifted, explaining the rather time-coeval major decrease in sedimentation rates that occurred between 7 and $7.5 \mathrm{cal} \mathrm{ka}$, in core 92-12 and in others from near the modern $30 \mathrm{~m}$ isobath of the eastern Laptev Sea [Bauch et al., 2001b].

[20] A comparison of our diatom-based salinity record from core 92-12 with independent data from the site further east in the Yana Valley reveals striking similarities in terms of both timing and the interpretation of proxy records (Figure 7). In core PM9462, the occurrence of high proportions of freshwater palynomorphs (green algae) together with increased deposition of sand is clear evidence of a near-coastal, river-influenced environment [Bauch et al., 2001a]. In cores PM9462 and 92-12, the most drastic changes in the proxy records had ceased after $7.4 \mathrm{cal} \mathrm{ka}$, leaving little doubt that the changes at the two sites were not caused by one and the same predominant process.

[21] Because the modern distributional pattern of the relative abundance of the main ecological groups and concentration of diatom valves in the surface sediments from the Laptev and Kara seas show a strong relationship with salinity, ice conditions and sedimentation processes within the zone of intermixing between riverine and shelf waters [this study; Bauch and Polyakova, 2000; Polyakova, 2003], the temporal variations in composition of diatom assemblages recognized in core $92-12$ for the past 9 cal ka are bound to reflect changes in all of these environmental parameters. The reconstructed salinity of $\sim 9$ due to the occurrence of some marine diatoms in the lowermost part of the core testifies that the study area was already under some marine influence by 9 cal ka (Figure 7). This assumption is also supported by the identification of Macoma sp. at $500 \mathrm{~cm}$ core depth (Table 1) and, most of

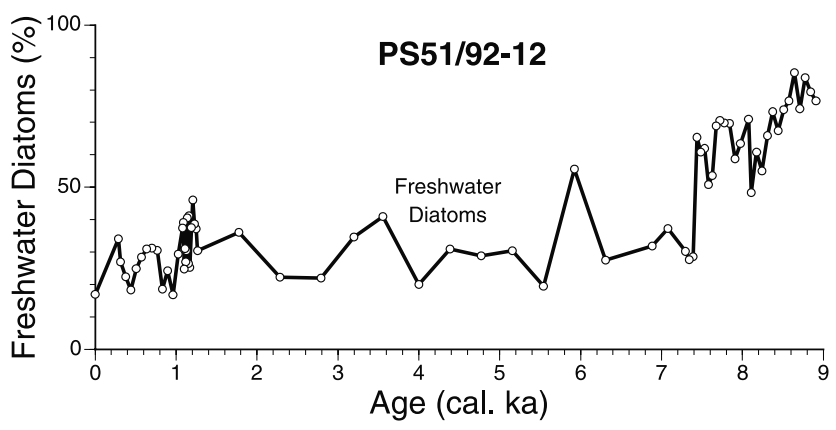

Figure 6. Relative abundance of freshwater diatoms in core PS51/92-12. 

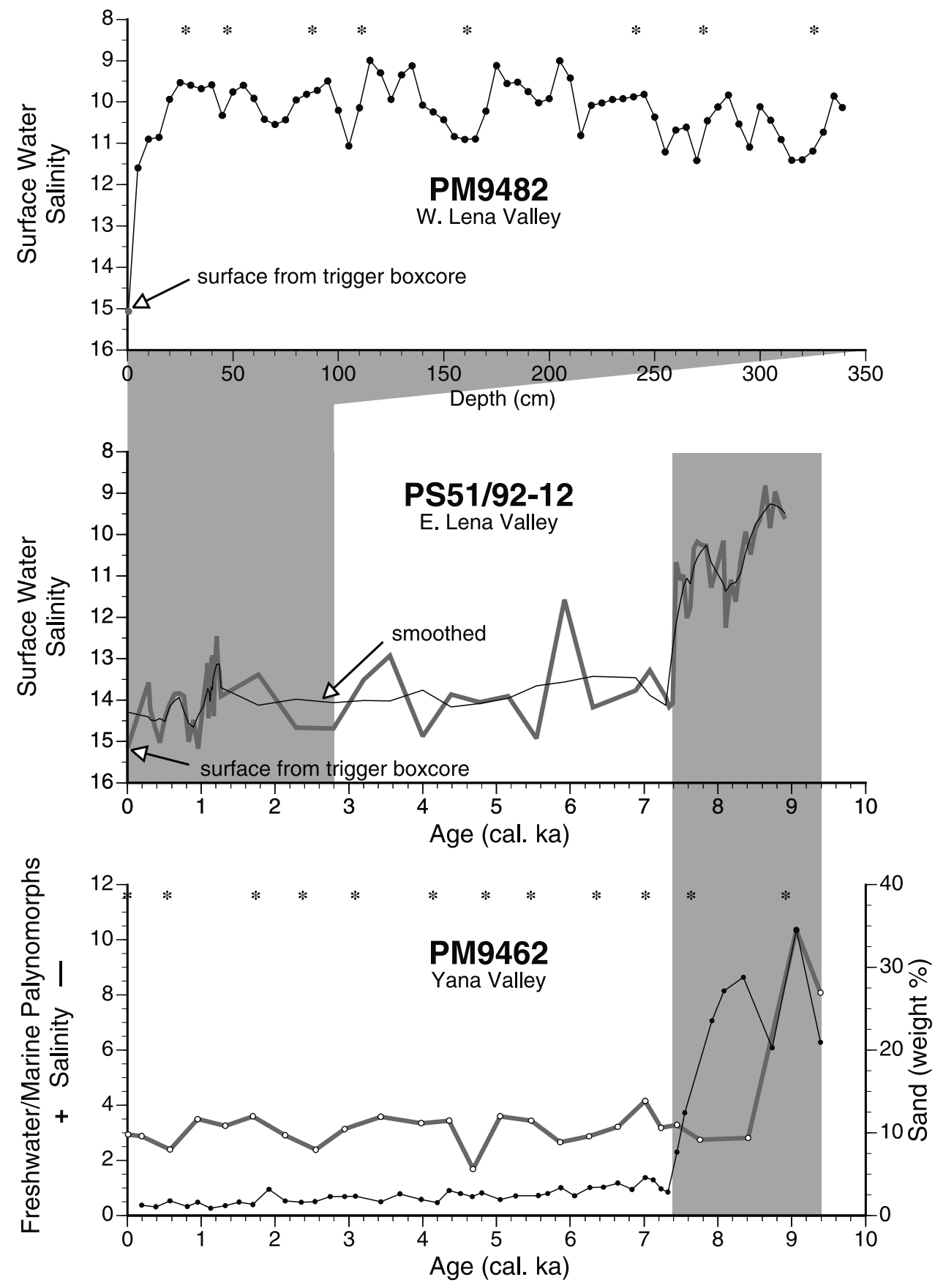

Figure 7. Reconstructed surface salinities in core PS51/92-12 for the last 9 cal ka. Data are compared with a salinity record calculated from freshwater diatoms in core PM9482, which dates back to about 2.8 cal ka [Bauch and Polyakova, 2000], and sedimentological (filled circles) as well as micropaleontological (open circles) records from core PM9462 [Bauch et al., 2001a]; asterisks mark position of AMS ${ }^{14} \mathrm{C}$-dates.

all, by the recognition of the low-salinity-tolerating benthic foraminifer Elphidium incertum already at $545 \mathrm{~cm}$ core depth (E. Taldenkova, personal communication, 2002). However, the salinity fluctuations between 9 and 14 indicate that paleoenvironmental conditions between 9 and 7.4 cal ka differed from the time afterward. The distinct and sharp decreases in relative abundance of freshwater diatoms observed at $7.4 \mathrm{ka}$, in particular, gives further evidence for a significant overall change in surface water properties.

[22] The very low salinities reconstructed for the time between 9 and 8.6 cal ka thus indicate a near-coastal and river-influenced environment. It may be assumed from the nature of the modern shelf topography that no delta system existed at times when sea level was lower than at present. 
Since sea level highstand was reached at about $5 \mathrm{cal} \mathrm{ka,} \mathrm{it} \mathrm{is}$ evident that the present Lena Delta is a fairly young, Late Holocene feature [Schwamborn et al., 2002]. Moreover, the channel-like topography at site 92-12 implicates that the Lena paleoriver mouth at this time more likely resembled an estuarine system (Figure 2), similar to the modern $\mathrm{Ob}$ and Yenisey rivers. Implying such a depositional setting may also help to explain the very high diatom concentrations values recognized between 9 and $8.6 \mathrm{ka}$. In other Arctic estuarine systems, the intermixing zone of riverine and marine waters is typically characterized by increased precipitation of suspended organic matter [Lisitzin, 1999]. Because a substantial part of the suspended organic matter also consists of diatom plankton unloaded from the river summer plume, the unusually high diatom concentrations may be regarded as additional evidence for a proximal coastal-estuarine position of core 92-12 during this time. This assumption is supported by the sediment composition in core PM9462 (Figure 7) which shows that the depositional setting of the $32 \mathrm{~m}$ paleoisobath was still of a fluvial kind between 9.4 and 9 cal ka [Bauch et al., 2001a].

[23] Increasing salinity up to about 14 until 7.4 cal ka gives evidence for the further environmental changes which were associated with the southward migration of the coast relative to the core site. The average values of about $60 \%$ of freshwater diatoms prior to $7.4 \mathrm{cal} \mathrm{ka}$ implicate a salinity range between 10 and 12 . These values are quite typical today for the inner shelf zone adjacent to the Lena Delta (Figure 3), emphasizing once again the validity of our freshwater diatom/salinity correlation derived from the modern analogue approach on the basis of the Kara Sea data set.

[24] At about 7.4 cal ka marine diatoms, notwithstanding the variability in the total amount of diatom valves, became the dominant group (Figure 5). At this time the boreal forest experienced its northernmost expansion in Eurasia [MacDonald et al., 2000] together with marked lacustrine depositional changes just south of the Lena Delta [Laing et al., 1999], both implying wetter conditions during the midHolocene probably due to an increasing maritime climate caused by a sea level stand already close to the present [Bauch et al., 2001b]. Such a scenario is also in accordance with palynological records, showing that warmest conditions existed in the near-coastal areas of the Laptev Sea hinterland between 9 cal ka and 4 cal ka [Pisaric et al., 2001].

[25] Pollen and oxygen isotopic data have shown that after about 4 cal ka climate became cooler again and moisture conditions stabilized along the northern Siberian margin [Wolfe et al., 2000; Pisaric et al., 2001]. Although average abundance of freshwater diatoms in core 92-12 remained on a relatively even level of about $30 \%$ since 7.4 $\mathrm{cal} \mathrm{ka}$, the fluctuations noted during the last $3.5 \mathrm{cal} \mathrm{ka}$ would still indicate changes in salinity between 12.5 and 15. Intriguingly, a variability in surface salinity of the order of 2.5 units is exactly what we would reconstruct from core PM9482 for approximately the same time interval (Figure 7).

[26] On the basis of our constructed salinity records the question remains to what extent climate amelioration after the last glaciation has also contributed to variations in the volume of Siberian river runoff with possible consequences on the hydrological conditions beyond the Laptev Sea region. Although monitoring over the last 50 years has unveiled some considerable variability in interannual river discharge and surface salinity patterns [Global Runoff Data Center, 1998; Environmental Working Group (EWG), 1998], it now seems evident that surface property changes in the Arctic Ocean and on the adjacent shelves are also the result of large-scale atmospheric pressure variations with a relatively short cyclicities [Proshutinsky and Johnson, 1997; Mysak, 2001]. A systematic, cyclic nature of Arctic climate behavior appears to have been a persistent feature also during the last few centuries [Overpeck et al., 1997]. Thus it may well be that the surface salinity fluctuations observed by us for the last $4 \mathrm{kyr}$ is the result of a relatively stabilized climate in northern Siberia that, nevertheless, bears an inherent natural variability.

\section{Summary}

[27] Using the modern relationship between the relative abundance of freshwater diatoms, as found in the surface sediments from the estuarine bays region of the inner Kara Sea with the summer surface water salinity from that area, a correlation was established that allows to reconstruct past salinities on Siberian shelves. On the basis of diatom distribution patterns in a sediment core obtained to the northeast of the Lena Delta, the impact of the riverine runoff from the Lena River on the shelf hydrology was reconstructed since about $9 \mathrm{cal} \mathrm{ka}$. The salinity reconstruction enabled us to make further assumptions on the relative distance of the studied site to the coast, and thus, on parts of the Holocene transgression. To further support our interpretations, comparisons were carried out with independent proxy records from two other sites.

[28] Because of the presence of marine diatoms, it can be inferred that the main study site in the eastern Lena Valley was already flooded by the postglacial Holocene transgression around $9 \mathrm{cal} \mathrm{ka}$. However, on the basis of our modern analogue method using the Kara Sea data set, the very high abundances of riverine freshwater diatoms found between 9 and 8.6 cal ka clearly indicate a near-coastal, probably outer-estuarine environment. The high proportions of freshwater diatoms of $85 \%$ translate into a salinity of about 9 for this time interval.

[29] Due to the continuing southward shift of the Lena River mouth relative to the study site, a further increase of salinities up to 14 is reconstructed until $7.4 \mathrm{cal} \mathrm{ka}$. when a strong decrease in freshwater diatom abundance is observed coincident with a major reduction in sedimentation rate. Together with independent sand-size fraction data from another core further to the east, the change in the input of sediments at the study site is interpreted as additional evidence for the increasing distance between coastline and core site during the interval 7.4 and $7 \mathrm{cal} \mathrm{ka}$.

[30] After $7.4 \mathrm{cal} \mathrm{ka,} \mathrm{average} \mathrm{salinities} \mathrm{northeast} \mathrm{of} \mathrm{the}$ Lena Delta appear to have been relatively constant but, nevertheless, fluctuated between 12.5 and 15 , especially since about 3.5 cal ka when climate conditions cooled along 
the north Siberian margin. Salinity fluctuations of similar magnitude are also observed in a diatom-inferred record from further west (western Lena Valley), which covers approximately the same time interval, implying that our salinity reconstruction for the eastern Lena Valley is not a local phenomenon but an overall reflection of Lena River discharge during this time.

[31] The more recent changes in the records may be regarded as part of the natural variability of the Arctic climate in general, because a certain variability is also recognized in many other proxy records of the Arctic. In this context, our diatom-based study clearly indicates the potential of this proxy to reconstruct Arctic river-runoff patterns on various timescales. Future studies, on other
Siberian shelves as well as in combination with proxies such as isotopes and other fossil groups, will allow us to expand our knowledge about this crucial environmental process within the Arctic climate system.

[32] Acknowledgments. Our thanks are expressed to the scientists and crews of R/V Akademik Ivan Petrov, R/V Polarstern, and R/V Professor Multanovsky who assisted in obtaining the sediments from the Kara and Laptev seas. We are grateful to S. Kirillov and I. Dmitrenko for compiling the salinity maps for the Kara and Laptev seas which also include the new data from the 1990s. The study received financial support from the German and Russian ministries of science and technology (projects SIRRO and Laptev Sea System 2000). All data will be made available through the PANGAEA data managing system (http://www.pangaea.de). This is a contribution to QUEEN (Quaternary Environment of the Eurasian North), a program of the European Science Foundation.

\section{References}

Aagaard, K., A synthesis of the Arctic Ocean circulation, Phys. Chem. Oceanogr., 188, $11-22,1989$

Aagaard, K., and E. C. Carmack, The role of sea ice and other freshwater in the Arctic circulation, J. Geophys. Res., 94(C10), 14,48514,498, 1989.

Aksenov, A. A., H. H. Dunaev, A. S. Ionin, V. V. Kalinenko, V. S. Medvedev, Y. A. Pavlidis, and M. G. Yurkevich, Eurasian Arctic Shelf During the Late Quaternary Time (in Russian), pp. 1-277, Nauka, Moscow, 1987.

Battarbee, R. W., A new method for estimation of absolute microfossil numbers, with reference especially to diatoms, Limnol. Oceanogr., 18, 647-653, 1973

Bauch, D., P. Schlosser, and R. Fairbanks, Freshwater balance and the sources of deep and bottom waters in the Arctic Ocean inferred from the distribution of $\mathrm{H}_{2}{ }^{18} \mathrm{O}$, Progr. Oceanogr., 35, 53-80, 1995.

Bauch, H. A., and Y. I. Polyakova, Late Holocene variations in Arctic shelf hydrology and sea-ice regime: Evidence from north of the Lena Delta, Int. J. Earth Sci., 89(3), 569577, 2000.

Bauch, H. A., H. Kassens, H. Erlenkeuser, P. M. Grootes, and J. Thiede, Depositional environment of the Laptev Sea (Arctic Siberia) during the Holocene, Boreas, 28, 194-204, 1999.

Bauch, H. A., H. Cremer, and M. Kunz-Pirrung, Siberian shelf sediments contain clues to paleoclimate forcing, EOS Trans. $A G U, 81$, $233-238,2000$

Bauch, H. A., H. Kassens, O. D. Naidina, M. Kunz-Pirrung, and J. Thiede, Composition and flux of Holocene sediments on the eastern Laptev Sea shelf, Arctic Siberia, Quat. Res., 55(3), 344-351, 2001a.

Bauch, H. A., T. Mueller-Lupp, R. F. Spielhagen, E. Taldenkova, H. Kassens, P. M. Grootes, J. Thiede, J. Heinemeier, and V. V. Petryashov, Chronology of the Holocene transgression at the northern Siberian margin, Global Planet. Change, 31(1-4), 123-137, 2001b.

Cremer, H., The diatom flora of the Laptev Sea (Arctic Ocean), Bibliotheca Diatomolog., 40, $1-169,1998$

Cremer, H., Distribution patterns of diatom surface sediment assemblages in the Laptev Sea (Arctic Ocean), Mar. Micropaleontol., 38, 3967, 1999.

Dickson, B., All change in the Arctic, Nature, 397, 389-391, 1999.

Dmitrenko, I., P. Golovin, V. Gribanov, H. Kassens, and J. Hölemann, Influence of the summer river runoff on ice formation in the Kara and Laptev Seas, in Ice in Surface Waters, Proceedings of the 14th International Symposium on Ice, edited by T. S. Hung, pp. 251-257, A. A. Balkema, Brookfield, Vt., 1998 .

Dmitrenko, I. A., V. A. Gribanov, D. L. Volkov, H. Kassens, and H. Eicken, Impact of river discharge on the sea-land fast ice extension in the Russian Arctic shelf area, in Proceedings of the 15th International Conference on Port and Ocean Engineering Under Arctic Conditions, edited by J. Tuhkuri and K. Riska, pp. 311-321, Helsinki Univ. of Technol., Espoo, Netherlands, 1999a.

Dmitrenko, I., P. Golovin, V. Gribanov, and H. Kassens, Oceanographic causes for transarctic ice transport of river discharge, in LandOcean Systems in the Siberian Arctic: Dynamics and History, edited by H. Kassens et al., pp. $73-$ 92, Springer-Verlag, New York, 1999b.

Eicken, H., E. Reimnitz, V. Alexandrov, T. Martin, H. Kassens, and T. Viehoff, Sea-ice processes in the Laptev Sea and their importance for sediment export, Cont. Shelf Res., 17(2), 205-233, 1997.

Environmental Working Group (EWG), Oceanography atlas for the summer period, in Joint U.S.-Russian Atlas of the Arctic Ocean [CD-ROM], Univ. of Colo., Boulder, Colo., 1998

Fahl, K., and R. Stein, Biomarkers as organiccarbon-source and environmental indicators in the late Quaternary Arctic Ocean, Mar. Chem., 63(3/4), 293-309, 1999.

Global Runoff Data Center, Bundesanstalt für Gewässerkunde, Koblenz, Germany, 1998.

Gordeev, V. V., J. M. Martin, I. S. Sidorov, and M. V. Sidorova, A reassessment of the Eurasian river input of water sediment, major elements, and nutrients to the Arctic, Am. J. Sci., 296, 664-691, 1996

Grebmeier, J. M., W. O. J. Smith, and R. J. Conover, Biological processes on Arctic continental shelves: Ice-ocean-biotic interactions, in Arctic Oceanography: Marginal Ice Zones and Continental Shelves: Coastal and Estuarine Studies, edited by W. O. J. Smith and J. M. Grebmeier, pp. 231-261, AGU, Washington, D. C., 1995.

Holmes, M. L., and J. S. Creager, Holocene history of the Laptev Sea continental shelf, in Arctic Ocean Sediments, Microfauna, and Climatic Record in Shelf, edited by Y. Herman, pp. 211-229, Springer-Verlag, New York, 1974
Ivanov, I. I., and A. A. Piskun, Distribution of river water and suspended sediments in the river deltas of the Laptev Sea, in Russian-German Cooperation: Laptev Sea System, Rep. Polar Res., 176, pp. 142-153, 1995.

Ivanov, I. I., and A. A. Piskun, Distribution of river water and suspended sediment loads in the deltas of rivers and basins of the Laptev and East Siberian seas, in LandOcean Systems in the Siberian Arctic: Dynamics and History, edited by $\mathrm{H}$. Kassens et al., pp. 239-250, Springer-Verlag, New York, 1999.

Kassens, H., I. Dmitrenko, V. Rachold, J. Thiede, and L. Timokhov, Russian and German scientists explore the Arctic's Laptev Sea and its climate system, EOS Trans. $A G U, 79,317-$ 323, 1998

Kleiber, H. P., and F. Niessen, Late Pleistocene paleoriver channels on the Laptev Sea ShelfImplications from sub-bottom profiling, in Land-Ocean Systems in the Siberian Arctic: Dynamics and History, edited by H. Kassens et al., pp. 635-656, Springer-Verlag, New York, 1999.

Kunz-Pirrung, M., J. Matthiessen, and A. De Vernal, Late Holocene dinoflagellate cysts as indicators for short-term climate variability in the eastern Laptev Sea (Arctic Ocean), J. Quat. Sci., 16(7), 711-716, 2001.

Laing, T. E., K. M. Rühland, and J. P. Smol, Past environmental and climatic changes related to tree-line shifts inferred from fossil diatoms from a lake near the Lena River Delta, Siberia, The Holocene, 9(5), 547-557, 1999.

Lindemann, F., Sonographische und sedimentologische Untersuchungen in der Laptevsee, sibirische Arktis, MS thesis, 75 pp., Kiel Univ., Kiel, Germany, 1995.

Lisitzin, A. P., The continental-ocean boundary as a marginal filter of the World Oceans, in Biogeochemical Cycling and Sediment Ecology, edited by J. S. Grog et al., pp. 69-105, Kluwer Acad., New York, 1999.

MacDonald, G. M., et al., Holocene treeline history and climate change across northern Eurasia, Quat. Res., 53, 302-311, 2000.

Mueller-Lupp, T., H. A. Bauch, H. Erlenkeuser, J. Hefter, H. Kassens, and J. Thiede, Changes in the deposition of terrestrial organic matter on the Laptev Sea shelf during the Holocene: Evidence from stable carbon isotopes, Int. J. Earth Sci., 89(3), 563-568, 2000.

Mysak, L. A., Patterns of Arctic circulation, Science, 293, 1269-1270, 2001. 
Overpeck, J., et al., Arctic environmental change of the last four centuries, Science, 278, 12511256, 1997.

Peregovich, B., E. Hoops, and V. Rachold, Sediment transport to the Laptev Sea (Siberian Arctic) during the Holocene-Evidence from the heavy mineral composition of fluvial and marine sediments, Boreas, 28(1), 205-214, 1999.

Pisaric, M. F. J., G. M. MacDonald, A. A. Velichko, and L. C. Cwynar, The late-glacial and post-glacial vegetation history of the northwestern limits of Beringia based on pollen, stomate and tree stump evidence, Quat. Sci. Rev., 20(1-3), 235-245, 2001.

Pivovarov, S. V., J. A. Höleman, H. Kassens, M. Antonov, and I. Dmitrenko, Dissolved oxygen, silicon, phosphorous and suspended matter concentrations during the spring breakup of the Lena River, in Land-Ocean Systems in the Siberian Arctic: Dynamics and History, edited by H. Kassens et al., pp. 251-264, Springer-Verlag, New York, 1999.
Polyakova, Y. I., Diatom assemblages in surface sediments of the Kara Sea (Siberian Arctic) and their relationship to oceanological conditions, in Proceedings in Marine Science: Siberian River Run-off in the Kara Sea: Characterization, Quantification, Variability and Environmental Significance, edited by R. Stein et al., Springer-Verlag, New York, in press, 2003.

Proshutinsky, A. Y., and M. A. Johnson, Two circulation regimes of the wind-driven Arctic Ocean, J. Geophys. Res., 102, 12,493-12,514, 1997.

Schwamborn, G., V. Rachold, and M. N. Grigoriev, Late Quaternary sedimentation history of the Lena Delta, Quat. Int., 89, 119-134, 2002.

Stuiver, M., P. J. Reimer, E. Bard, J. W. Beck, G. S. Burr, K. A. Hughen, B. Cromer, G. McCormic, J. van der Plicht, and M. Spurk, INTCAL 98 radiocarbon age calibration, 24,000-0 cal BP, Radiocarbon, 40(3), 1041 1083, 1998.
Wegner, C., J. A. Hölemann, I. Dmitrenko, S. Kirillov, K. Tuschling, E. Abramova, and H. Kassens, Suspended particulate matter on the Laptev Sea shelf (Siberian Arctic) during ice-free conditions, Estuarine Coastal Shelf Sci., in press, 2002.

Wolfe, B. B., T. W. D. Edwards, R. Aravena, S. L. Forman, B. G. Warner, A. A. Velichko, and G. M. MacDonald, Holocene paleohydrology and paleoclimate at treeline, north-central Russia, inferred from oxygen isotope records in lake sediment cellulose, Quat. Res., 53, 319-329, 2000.

H. A. Bauch, GEOMAR Research Center for Marine Geosciences, Wischhofstrasse 1-3, D-

24148 Kiel, Germany. (hbauch@geomar.de)

Y. I. Polyakova, Department of Geography, Moscow State University, Vorobievy Gory, 119899 Moscow, Russia. 